\title{
SKILL ENTREPRENEUR DALAM MENINGKATKAN PROFITABILITAS PEDAGANG MUSLIM DI PASAR SUMPUT DRIYOREJO GRESIK
}

\author{
Sutono; Sofia \\ STAI Al Azhar Gresik \\ sutonostaialazhar@gmail.com; sofiastaialazhar@gmail.com
}

\begin{abstract}
Skills in the world of entrepreneurship are the characteristics, traits, knowledge, and abilities that underlie a person in working and operating everything related to the tasks being carried out so that their performance is adequate. The purpose of this study is to describe entrepreneur skills in increasing the profitability of Driyorejo Muslim traders. This study hopes to obtain a new concept about the importance of entrepreneurship skills for Muslim traders in the Sumput market Driyorejo in increasing profitability in a sustainable business. Descriptive analysis is used to describe the condition of the research object. This study is a causality study that is used to measure the strength of the relationship between two or more variables, as well as to show the direction of the relationship between the independent variable and the dependent variable or to question the cause and effect between variable $X$ and variable $Y$. This is evidenced through simple regression analysis and based on the results hypothesis testing using the T-test, it is found that Ho is rejected and Ha is accepted, which means that there is an influence between entrepreneurial skills on business profitability. Based on the results of this research, entrepreneurial skills influence the profitability of Driyorejo Muslim traders, Gresik regency.
\end{abstract}

Keywords: entrepreneur skill; Muslim trader; profitability

\section{Pendahuluan}

Pemerintah menekankan perkembangan industri kreatif yang diharapkan mampu menggerakkan ekonomi rakyat, membuka lapangan pekerjaan, serta mengurangi pengangguran dan kemiskinan, peningkatan kualitas hidup, pemerataan kesejahteraan dan pemanfaatan sumber daya menjadi produk bernilai yang pada akhirnya dapat meningkatkan perekonomian nasional. Salah satu yang mempengaruhi pertumbuhan dan perkembangan ekonomi suatu bangsa dapat dilihat dari pertumbuhan wirausaha pada setiap negara. ${ }^{1}$

Pemerintah membutuhkan banyak para entrepreneur atau wirausahawan karena mereka adalah agen perubahan ekonomi yang strategis sehingga Indonesia dapat berubah dari negara yang berpendapatan menengah ke bawah menjadi negara yang berpendapatan menengah ke atas. Kemampuan seorang entrepreneur yang memiliki skill dan kreatifitas yang dapat membuka lahan, ladang, bahkan ruang harapan hidup bagi pengangguran di Indonesia.

Keterampilan wirausaha atau skill entrepreneur adalah kemampuan menggunakan akal, fikiran, ide, dan kreatifitas dalam mengerjakan, mengubah ataupun membuat sesuatu menjadi lebih bermakna sehingga menghasilkan sebuah nilai dari hasil pekerjaan tersebut, atau lebih kongkritnya skill atau keterampilan adalah kemampuan untuk menerjemahkan pengetahuan ke

\footnotetext{
${ }^{1}$ Sutono, "Perilaku Konsumen Muslim dalam Mengkonsumsi Produk Halal Food Perspektif Maqāṣid al-sharī’ah al-Shatibi (Studi Pada Pasar Sepanjang Taman Sidoarjo)" (Tesis--UIN Sunan Ampel Surabaya, 2018), 8.
} 
dalam praktik sehingga tercapai hasil kerja yang diinginkan. Sedangkan entrepreneur diartikan sebagai penerapan kreativitas dan inovasi untuk memecahkan permasalahan dan upaya memanfaatkan peluang-peluang yang dihadapi orang lain. Entrepreneur mengarah pada orang yang melakukan usaha atau kegiatan sendiri dengan segala kemampuan yang dimilikinya.

Entrepreneur yang sukses memiliki berbagai keterampilan, di antaranya mengelola operasional usaha, selain produk dan pelayanan. Keterampilan ini mencakup pengelolaan rantai pasokan dan juga pengetahuan mengenai teknologi terbaru. Suatu kemampuan yang dimiliki oleh seorang pemimpin umtuk melakukan suatu pekerjaan. Walaupun seorang pemimpin memiliki karyawan yang bisa ia perintah untuk melakukan pekerjaan, namun seorang pemimpin harus mampu melakukan sendiri pekerjaan-pekerjaan tertentu, termasuk mampu mengawasi pekerjaan yang dilakukan oleh karyawannya. ${ }^{2}$

Seorang entrepreneur juga harus memiliki keterampilan dalam manajemen. Keterampilan ini sebagai atribut utama yang harus dimiliki seorang eksekutif untuk memenuhi tugas-tugas dalam suatu organisasi. Hal tersebut termasuk kapasitas untuk menunjukkan pekerjaan dalam sebuah organisasi sambil menghindari situasi krisis dan segera diselesaikan ketika hal itu terjadi. Keterampilan manajemen bisa dikembangkan melalui pembelajaran dan pengalaman praktis sebagai pengelola. Keterampilan itu membantu pengelola untuk berhubungan dengan sesama rekan kerja mereka dan mengetahui bagaimana cara berurusan dengan karyawan mereka yang akan membantu memudahkan aktifitas-aktifitas di suatu organisasi. ${ }^{3}$

Di samping itu, skill entrepreneurship adalah kemampuan individu untuk mewujudkan ide menjadi aksi nyata. Entrepreneurship mencakup kreatifitas, inovasi, dan pengambilan risiko, seperti kemampuan merencanakan dan mengelola pekerjaan untuk mencapai tujuan. Entrepreneur dipandang penting untuk mempromosikan inovasi, daya saing dan perkembangan ekonomi. Menumbuhkan semangat kewirausahaan mendukung adanya perusahaan baru dan perkembangan bisnis. Bagaimanapun juga, kemampuan wirausaha juga menyediakan manfaat terlepas dari pandangan mereka dalam melihat masa depan saat memulai bisnis. Skill entrepreneur bisa digunakan antara kehidupan pribadi dan orang lain karena mencakup kreativitas, inisiatif, keuletan, kerjasama, pemahaman resiko dan rasa tanggung jawab. ${ }^{4}$

Sementara pasar adalah tempat para entrepreneur untuk menawarkan produk yang dihasilkan dengan jumlah lebih dari satu. Area itu bisa berbentuk pusat perbelanjaan, pasar tradisional, pertokoan, mall, plaza, pusat perdagangan maupun sebutan lainnya. Pasar masa kini terbagi menjadi dua, yaitu pasar tradisional dan pasar modern. Pasar tradisional ialah pasar di mana entrepreneur dan pembeli bisa bertatap muka secara langsung, leluasa memilih barang, dengan pelayanan utama terletak pada pegawai dan pedagang itu sendiri, sistem pembayarannya pun masih bersifat manual, artinya masih menggunakan uang kertas maupun logam yang beredar. Berbeda dengan pasar modern yang mengutamakan self service dan

\footnotetext{
${ }^{2}$ Buchari Alma, Kewirausahaan untuk Mahasiswa dan Umum (Bandung: Alfabeta, 2016), 170.

3 https://Corporatefinanceinstitute.Com/Resources/Careers/Soft-Skills/Management-Skills/ diakses pada 2 September 2019.

${ }^{4}$ https://skillspanorama.cedefop.europa.eu/sites/default/files/EUSP_AH_Entrepreneurial_0.pdf diakses pada 2 Agustus 2019.
} 
pembayarannya pun banyak menggunakan sistem electronic data capture (EDC) dengan pemakaian credit card. ${ }^{5}$

Keberadaan pasar tradisional saat ini sedikit demi sedikit mulai tergeser dengan menjamurnya pasar modern. Namun, pasar tradisional tetap menjadi tumpuan utama perekonomian banyak masyarakat di Indonesia. Pasar tradisional yang tidak diharapkan kepunahannya, sedikit demi sedikit mendapatkan perhatian dari pemerintah setempat, mulai dari penataan ulang pasar dan renovasi kios untuk mestabilkan penjualan dan pembelian produk demi meningkatkan profitabilitas para pedagang. Hal ini menjadi daya tarik tersendiri bagi masyarakat Indonesia yang ingin memiliki usaha sendiri.

Profitabilitas adalah pengukur kemampuan perusahaan atas laba yang dihasilkan dari berbagai aktivitas perusahaan melalui sejumlah kebijakan dan keputusan yang dilakukan oleh perusahaan. ${ }^{6}$ Rasio profitabilitas mengukur laba dan keberhasilan operasi suatu perusahaan dalam suatu periode waktu tertentu. Laba atau rugi dapat mempengaruhi kemampuan sebuah usaha dalam memperoleh pendanaan yang diperlukan. Oleh karena itu, evaluasi terhadap kemampuan sebuah usaha selalu dilakukan, salah satunya dengan menggunakan profitabilitas sebagai tes akhir dalam menilai keefektifan operasi manajemen.

Untuk menilai profitabilitas bisa dilakukan dengan bermacam cara tergantung kebijakan perusahaan itu sendiri. Di antaranya melalui profit margin sebagai rasio yang digunakan untuk mengukur seberapa banyak keuntungan yang bisa diperoleh dari setiap penjualan. Rasio ini dapat diartikan pula sebagai kemampuan perusahaan dalam menekan biaya-biaya (ukuran efisiensi) di perusahaan pada periode tertentu. Artinya, ketika profit margin tinggi, menandakan bahwa perusahaan memiliki kemampuan menghasilkan laba yang tinggi pada tingkat penjualan tertentu, sedangkan profit margin yang rendah menandakan bahwa penjuaan telalu rendah pada tingkat biaya tertentu, atau biaya yang terlalu tinggi untuk tingkat penjualan tertentu, maupun kombinasi dari keduanya. ${ }^{7}$

Cara lain adalah dengan return on investment atau return on assets adalah kemampuan perusahaan dalam menghasilkan laba dengan total aset (kekayaan) yang dimiliki peru sahaan tersebut serta disesuaikan dengan biaya-biaya utuk mendanai aset tersebut. Rasio ini digunakan untuk mengetahui efisiensi perusahaan dalam menggunakan aktiva yang digunakan untuk membiayai kegiatan operasional perusahaan. Perhitungan menggunakan rasio ini akan menunjukkan ukuran yang lebih baik atas profitabilitas perusahaan karena menunjukkan efektivitas manajemen dalam menggunakan aktivanya untuk memperoleh pendapatan. ${ }^{8}$

Ada yang juga melalui cara return on equity adalah kemampuan perusahaan menghasilkan laba untuk pemegam saham biasa dengan memperhitungkan biaya hutang dan dividen saham preferen sebelumnya. Dengan kata lain, return on equity adalah bentuk kemampuan sebuah usaha dalam menghasilkan laba kepada mitra bisnis yang ikut

\footnotetext{
${ }^{5}$ Sutono, "Perilaku Konsumen Muslim", 9.

${ }^{6}$ Agus Wibowo dan Sri Wartini, "Efisiensi Modal Kerja, Likuiditas dan Leverage Terhadap Profitabilitas Pada Perusahaan Manufaktur di BEI”, Jurnal Dinamika Manajemen, Volume 3, Nomor 1 (Maret 2012), 51.

${ }^{7}$ Ibid.

8 Putri Pratama dan Jaharuddin, "Rekonstruksi Konsep Profitabilitas dalam Perspektif Islam", IkraithHumaniora, Volume 2, Nomor 1 (2018), 163.
} 
menanamkan modal bagi usahanya. Rasio ini merupakan ukuran profitabilitas dalam sudut pandang pemegang saham, bukan sebagai pengukur return saham sebenarnya. ${ }^{9}$

Melihat di Kecamatan Driyorejo, yang berbatasan langsung dengan wilayah Surabaya pada sisi timur, serta berbatasan langsung dengan Kabupaten Sidoarjo pada sisi selatan, merupakan sebuah kecamatan yang penuh dengan usaha industri pabrik. Mayoritas penduduknya pun bekerja sebagai buruh pabrik. Beberapa kelompok masyarakat lainnya memilih bekerja sebagai pedagang di mana telah disediakan dua pasar di Kecamatan Driyorejo, yakni Pasar Petiken dan Pasar Sumput.

Sebagai kawasan yang dilingkari oleh dunia industri dengan pengaruh tingginya UMK dari rata-rata UMP, banyak perusahaan yang melakukan pemutusan hubungan kerja (PHK) kepada para karyawannya. Hal ini menyebabkan adanya keinginan untuk memiliki usaha sampingan sebagai tabungan apabila suatu saat nanti pihak pabrik melakukan PHK, baik tanpa pesangon maupun dengan pesangon. ${ }^{10}$

Memilih usaha di bidang perdagangan tentunya sudah menyiapkan banyak hal, mulai dari modal, waktu, serta mental. Modal yang dipakai pun tidak sedikit mengingat adanya sewa kios yang harus dibayarkan selain mempersiapkan modal untuk membeli barang dagangannya. Begitu pula menyiapkan waktu untuk terjun dalam dunia perdagangan yang membutuhkan kepekaan serta keahlian agar tidak salah langkah dalam berdagang. Persiapan mental dengan bertemu banyaknya pembeli agaknya butuh persiapan yang matang agar tidak mudah down saat bertemu dengan pembeli yang mendikte pedagang.

Selain modal yang harus dipersiapkan, pedagang juga harus terampil dalam menjalankan usahanya. Keterampilan berwirausaha yang dimaksudkan ialah kemampuan mengubah sesuatu menjadi lebih baik. Dimulai dari mengatur strategi pemasaran, strategi pemilihan lokasi, persiapan menghadapi daya saing antar sesama pedagang, ${ }^{11}$ melek terhadap teknologi, kemampuan mengelola pembukuan, pengelolaan stok, menjadi pemimpin yang baik bagi karyawannya, ${ }^{12}$ memiliki kemampuan berkomunikasi, baik dengan pelanggan maupun dengan rekan usahanya.

Selain itu, keterampilan dalam mengelola pembukuan tidak banyak dimiliki oleh pedagang pasar di mana pembukuan dianggap sebagai hal yang rumit untuk dilakukan walapaun hanya sekedar pembukuan sederhana. Para pedagang berprinsip selama keuntungan sudah bisa terlihat, tanpa adanya pembukuan, usaha dagang yang mereka jalankan akan tetap lancar. Dalam pengelolaan stok, pedagang juga hanya mengandalkan penglihatannya terhadap stok yang ada tanpa memiliki pembukuan atau catatan stok barang dalam toko.

\section{Metodologi Penelitian}

Jenis penelitian ini merupakan penelitian kausalitas yang digunakan untuk mengukur kekuatan hubungan antara dua variabel atau lebih, juga untuk menunjukkan arah hubungan antara variabel bebas dan variabel terikat atau mempertanyakan sebab-akibat antara varibel $\mathrm{X}$

\footnotetext{
${ }_{9}^{9}$ Ririn Setiorini, “Analisis Pengaruh Modal Kerja Terhadap Profitabilitas Pada Perusahaan Manufaktur yang Terdapat di Bursa Efek Indonesia (BEI)", (Skripsi--UIN Syarif Hidayatullah Jakarta, 2009), 27.

${ }^{10}$ Sutik, Wawancara, Driyorejo, 16 Februari 2019.

${ }^{11} \mathrm{http}: / /$ repository.usu.ac.id/bitstream/123456789/42871/4/Chapter\%20II.pdf diakses pada 22 Februari 2019.

12 http://eprints.stainkudus.ac.id diakses pada 22 Februari 2019.
} 
dan variabel Y. ${ }^{13}$ Penelitian ini adalah penelitian kuantitatif karena data yang diperoleh berupa angka dan dianalisis menggunakan statistik. Alat yang digunakan dalam metode kuantitatif adalah kuesioner yang disebarkan kepada sampel dari populasi yang sudah ditentukan.

Adapun teknik pengumpulan data menggunakan kuesioner, ${ }^{14}$ dokumentasi, ${ }^{15}$ dan wawancara penelitian. ${ }^{16}$ Sedangkan teknik analisis data menggunakan uji asumsi klasik yang terdiri dari uji normalitas ${ }^{17}$ dan uji linearitas. ${ }^{18}$ Untuk menguji instrumen digunakan uji validitas, yaitu pengukuran yang menunjukan tingkat ketepatan ukuran suatu instrumen terhadap suatu konsep yang diteliti dan reabilitas untuk mengukur hasil data tetap konsisten. Penelitian ini juga menggunakan uji hipotesis melalui analisis regresi $\operatorname{linier}^{19}$ dan uji $\mathrm{T}$ atau uji parsial yang digunakan untuk menguji bagaimana pengaruh masing-masing variabel bebasnya secara sendiri-sendiri terhadap variabel terikatnya. ${ }^{20}$

\section{Gambaran Umum Pasar Sumput Driyorejo Gresik}

Pasar Sumput Driyorejo Gresik didirikan sejak tahun 2000. Letak Pasar Sumput termasuk strategis karena berada di tengah kecamatan Driyorejo yang mudah dijangkau oleh masyarakat. Bapak Rohim sebagai kepala pasar saat ini, kurang bisa menjelaskan sejarah dan perkembangan Pasar Sumput sejak awal berdirinya. Namun pada tahun 2018, Pasar Sumput menjadi juara 1 lomba pasar tingkat Kabupaten Gresik tetapi gagal ketika maju di tingkat provinsi. ${ }^{21}$ Pasar sumput saat ini memiliki kurang lebih 274 kios dengan total pedagang sebanyak 150 orang.

\section{Keterampilan Berwirausaha Pedagang Muslim di Pasar Sumput Driyorejo Gresik}

Dalam menjalankan suatu usaha diperlukan sebuah keterampilan untuk mengelola usaha tersebut agar tetap berjalan dan memberikan keuntungan pada pemilik usaha tersebut. Keterampilan meliputi kemampuan menguasai lingkungan, kemampuan mengelola administrasi usaha yang dijalani, kemampuan dalam menjalin sebuah kerjasama serta kemampuan pembawaan diri yang baik.

Berdasarkan hasil penelitian yang dilakukan kepada 30 pedagang muslim di pasar dengan cara melakukan penyebaran kuesioner diperoleh hasil bahwa keterampilan yang dimiliki sebagian pedagang dinilai tinggi dilihat dari jawaban yang diberikan responden yang berkisar antara $70 \%$ sampai dengan $81 \%$ pada masing-masing indikator. Jawaban tertinggi terdapat pada indikator personal maturity skill dengan presentase $81,16 \%$ dan jawaban

\footnotetext{
${ }^{13}$ Puguh Suharso, Metode Penelitian Kuantitatif untuk Bisnis: Pendekatan Filosofi dan Praktis (Jakarta: Indeks, 2009), 11.

${ }^{14}$ Sugiyono, Metode Penelitian Kuantitatif, Kualitatif, Dan R\&D (Bandung: Alfabeta, 2012), 142.

${ }^{15}$ Puguh Suharso, Metode Penelitian Kuantitatif, 104.

${ }^{16}$ Ibid., 83.

17 Anwar Hidayat, "Penjelasan Tentang Uji Normalitas dan Metode Perhitungan" dalam http://www.statistikian.com/2013/uji-normalitas.html diakses pada 7 Desember 2018.

18 Sahid Raharjo, "Cara Melakukan Uji Linearitas dengan Program SPSS" dalam https://www.spssindonesia.com/2014/02/uji-linearitas-dengan-program-spss.html? diakses pada 29 Desember 2018.

19 https://www.spssindonesia.com/2017/03/uji-analisis-regresi-linear-sederhana.html?m=1 diakses pada 9 Desember 2018.

${ }^{20}$ Setiawan dan Dwi Endah Kusrini, Ekonometrika (Yogyakarta: Andi Offset, 2010), 61.

${ }^{21}$ Rohim, Wawancara, Driyorejo, 27 September 2019.
} 
terendah terdapat pada entrepreneurship skill dengan presentase 70\%. Pada indikator technical skill diketahui presentase jawaban yang didapatkan sebesar $80 \%$. Sedangkan untuk indikator management skill mendapat presentase jawaban sebanyak $71 \%$. Sehingga rata-rata keterampilan berwirausaha yang dimiliki pedagang di Pasar Sumput didapatkan presentase sebesar 74,14\% dengan kategori tinggi. Artinya, bahwa keterampilan berwirausaha yang dimiliki oleh pedagang muslim di Pasar Sumput Driyorejo dapat menunjang profitabilitas.

\section{Profitabilitas Usaha Pedagang Muslim di Pasar Sumput Driyorejo Gresik}

Bagi pedagang, keuntungan adalah salah satu hal penting yang harus didapatkan demi kelangsungan usaha yang sedang dijalani. Dari keuntungan yang bisa dikumpulkan menjadi modal selanjutnya. Profitabilitas, sebagai salah satu penghitungan keefektifan penggunaan keuangan dilakukan agar kelangsungan dan kemajuan usaha bisa diperhitungkan secara matang. Dihitung mulai dari mencari laba bersih yang didapatkan sampai menghitung seluruh aset yang dimiliki. Berikut tabulasi data profitabilitas usaha yang didapatkan oleh pedagang muslim di Pasar Sumput Driyorejo.

Tabel 1.1. Data Profitabilitas Usaha Pedagang Muslim di Pasar Sumput Driyorejo Gresik

\begin{tabular}{|c|c|c|c|c|}
\hline Responden & $\begin{array}{c}\text { Laba Bersih } \\
\text { (Rupiah) }\end{array}$ & $\begin{array}{c}\text { Aset Rata-Rata } \\
\text { (Rupiah) }\end{array}$ & Presentase & $\%$ \\
\hline r1 & 166.900 .000 & 198.000 .000 & 0,842929293 & 84,29 \\
\hline r2 & 56.500 .000 & 107.900 .000 & 0,523632994 & 52,36 \\
\hline r3 & 3.776 .000 & 11.800 .000 & 0,32232105 & 32,00 \\
\hline $\mathrm{r} 4$ & 163.510 .000 & 115.510 .000 & 1,415548437 & 141,55 \\
\hline $\mathrm{r} 5$ & 107.650 .000 & 123.250 .000 & 0,873427992 & 87,34 \\
\hline r6 & 66.200 .000 & 53.530 .000 & 1,236689707 & 123,66 \\
\hline $\mathrm{r} 7$ & 39.645 .000 & 39.645 .000 & 1 & 100 \\
\hline $\mathrm{r} 8$ & 40.000 .000 & 90.500 .000 & 0,44198895 & 44,19 \\
\hline r9 & 222.256 .000 & 287.850 .000 & 0,77212437 & 77,21 \\
\hline r10 & 57.450 .000 & 52.950 .000 & 1,084985836 & 108,49 \\
\hline r11 & 39.650 .000 & 53.800 .000 & 0,736988848 & 73,69 \\
\hline r12 & 105.850 .000 & 294.000 .000 & 0,360034014 & 36,00 \\
\hline r13 & 279.460 .000 & 178.000 .000 & 1,57 & 157 \\
\hline r14 & 28.600 .000 & 16.600 .000 & 1,722891566 & 172,29 \\
\hline r15 & 9.480 .000 & 7.900 .000 & 1,2 & 120,00 \\
\hline r16 & 513.915 .000 & 533.915 .000 & 0,962540854 & 96,25 \\
\hline r17 & 300.905 .000 & 270.405 .000 & 1,112793772 & 111,27 \\
\hline r18 & 8.750 .000 & 47.000 .000 & 0,186170213 & 18,61 \\
\hline r19 & 280.260 .000 & 268.010 .000 & 1,04570725 & 104,57 \\
\hline $\mathrm{r} 20$ & 6.300 .000 & 9.950 .000 & 0,633165829 & 63,31 \\
\hline $\mathrm{r} 21$ & 16.420 .000 & 29.920.000 & 0,548796791 & 54,87 \\
\hline $\mathrm{r} 22$ & 104.970 .000 & 97.970 .000 & 1,071450444 & 107,14 \\
\hline $\mathrm{r} 23$ & 33.430 .000 & 23.930 .000 & 1,396991224 & 139,69 \\
\hline
\end{tabular}




\begin{tabular}{|l|r|r|r|c|}
\hline r24 & 45.000 .000 & 90.000 .000 & 0,5 & 50 \\
\hline r25 & 96.250 .000 & 182.730 .000 & 0,526733432 & 52,67 \\
\hline r26 & 603.565 .000 & 576.315 .000 & 1,04728317 & 104,72 \\
\hline r27 & 70.500 .000 & 109.470 .000 & 0,644012058 & 64,40 \\
\hline r28 & 14.355 .000 & 19.800 .000 & 0,725 & 72,5 \\
\hline r29 & 58.000 .000 & 109.210 .000 & 0,531086897 & 53,10 \\
\hline r30 & 36.250 .000 & 41.285 .000 & 0,878042873 & 87,80 \\
\hline
\end{tabular}

Dari tabel di atas, dapat diketahui jumlah laba bersih dan aset rata-rata yang didapatkan pedagang muslim di Pasar Sumput per Januari 2019 sampai dengan September 2019. Melalui rumus perhitungan profitabilitas usaha didapatkan presentase profitabilitas usaha pedagang muslim di Pasar Sumput Driyorejo dari presentase terendah, yaitu 18,61\% hingga presentase tertinggi, yaitu $172.29 \%$. Sehingga didapatkan pula presentase rata-rata yang didapatkan pedagang muslim Pasar Sumput Driyorejo sebesar 86,36\%.

\section{Analisis Hubungan Antar Variabel}

\section{Uji Normalitas}

Uji normalitas bertujuan untuk menguji apakah dalam model regresi, variabel pengganggu atau residual memiliki distribusi normal. Uji normalitas data dalam penelitian ini dilakukan dengan cara uji Kolmogorov-Smirnov. Hasil analisis ini kemudian dibandingkan dengan nilai kritisnya dengan kriteria apabila tingkat signifikansi $(\mathrm{Sig})>\alpha=0,05$, maka data berdistribusi normal, begitu juga sebaliknya. ${ }^{22}$

Tabel 1.2. Hasil Uji Normalitas One-Sample Kolmogorov-Smirnov Test

\begin{tabular}{|ll|r|}
\hline & & Unstandardized Residual \\
\hline N & Mean & 30 \\
& Std. &, 0000000 \\
& Deviation & 34,14184485 \\
& Absolute &, 108 \\
Most Extreme Differences & Positive &, 108 \\
& Negative &,- 054 \\
Kolmogorov-Smirnov Z & &, 590 \\
Asymp. Sig. (2-tailed) & &, 877 \\
\hline
\end{tabular}

Berdasarkan hasil uji di atas menggunakan uji Kolmogorov-Smirnov diketahui bahwa nilai Asymp. Sig. (2-tailed) sebesar 0,877 yang nilainya lebih besar dari 0,05. Maka sesuai dengan kriteria di atas dapat disimpulkan bahwa data dari variabel keterampilan berwirausaha dan profitabilitas usaha berdistribusi normal.

\footnotetext{
${ }^{22}$ Sofian Siregar, Metode Penelitian Kuantitatif: Dilengkapi dengan Perbandingan Perhitungan Manual dan SPSS (Jakarta: Kencana, 2017), 148.
} 


\section{Uji Linearitas}

Linieritas adalah sebuah uji yang bertujuan untuk mengetahui apakah dua variabel mempunyai hubungan yang linear atau tidak secara signifikan. Dua variabel dikatakan mempunyai hubungan yang linear jika signifikansi (linearity) kurang dari 0,05 dan jika signifikasi (sig. deviation from linearity) lebih besar dari 0,05. Persamaannya regresi linier dapat digunakan adalah nilai sig. linearity $<0,05$ dan nilai sig. deviation from linearity $>0,05$.

Tabel 1.3. Hasil Uji Linearitas

ANOVA Table

\begin{tabular}{|c|c|c|c|c|c|c|c|}
\hline & & & $\begin{array}{l}\text { Sum of } \\
\text { Squares }\end{array}$ & $\mathrm{df}$ & $\begin{array}{l}\text { Mean } \\
\text { Square }\end{array}$ & $\mathrm{F}$ & Sig. \\
\hline \multirow{7}{*}{$\begin{array}{l}\text { Profitabilitas } \\
\text { usaha * } \\
\text { keterampilanbe } \\
\text { rwirausaha }\end{array}$} & Between & (Combined) & 38713,329 & 19 & 2037,544 & 5,666 & , 004 \\
\hline & Groups & Linearity & 8504,883 & 1 & 8504,883 & 23,652 & , 001 \\
\hline & & Deviation & 30208,445 & 18 & 1678,247 & 4,667 & , 008 \\
\hline & & from & & & & & \\
\hline & & Linearity & & & & & \\
\hline & \multicolumn{2}{|c|}{ Within Groups } & 3595,856 & 10 & 359,586 & & \\
\hline & \multicolumn{2}{|l|}{ Total } & 42309,185 & 29 & & & \\
\hline
\end{tabular}

Berdasarkan tabel di atas dapat diperoleh nilai signifikansi pada linearity sebesar 0,001 lebih kecil dari 0,05 yang artinya variabel keterampilan berwirausaha sebagai variabel $\mathrm{X}$ berbanding tepat di garis lurus. Sedangkan nilai pada signifikasi deviation from linearity sebesar 0,008 lebih kecil dari 0.05 yang artinya bahwa tidak ada hubungan yang linear secara signifikan antara keterampilan berwirausaha dan profitabilitas usaha.

Selain dari taraf signifikansi, uji linearitas bisa dilihat pula dari kolom F, yaitu apabila $F_{\text {hitung }}>F_{\text {tabel, }}$ maka tidak ada hubungan linear yang signifikan antara variabel keterampilan berwirausaha dan profitabilitas usaha. Dari tabel di atas dapat diketahui nilai Fhitung sebesar 4,667 > $\mathrm{F}_{\text {tabel }}$ sebesar 2,80. Dari hasil tersebut dapat disimpulkan bahwa tidak ada hubungan yang linear secara signifikan antara keterampilan berwirausaha dan profitabilitas usaha.

\section{Uji Validitas}

Validitas adalah pengukuran yang menunjukkan tingkat ketepatan ukuran suatu instrumen terhadap suatu konsep yang diteliti. ${ }^{23}$ Uji validitas digunakan untuk mengukur ketepatan suatu item dalam kuesioner, apakah item dalam kuesioner tersebut sudah tepat sesuai dengan apa yang ingin diukur. Uji validitas pada penelitian ini menggunakan teknik korelasi product moment. Apabila $\mathrm{r}$ hitung lebih besar dari $\mathrm{r}$ tabel, maka kuesioner tersebut dikatakan valid. Sedangkan apabila $\mathrm{r}$ hitung lebih kecil dari $\mathrm{r}$ tabel, maka kuesioner tersebut dikatakan tidak valid. Dan nilai probabilitas korelasi $\{$ sig. (2-tailed) $\} \leq$ taraf signifikan 0.05 $(\alpha=5 \%)$.

Nilai $r$ tabel dengan jumlah 30 responden pada signifikansi 5\%, maka diketahui $\mathrm{r}$ hitung adalah 0,44. Sehingga, hasil uji valifitas dinyatakan valid dan dapat digunakan dalam penelitian ini.

\footnotetext{
${ }^{23}$ Puguh Suharso, Metode Penelitian Kuantitatif, 45.
} 
Tabel 1.4. Hasil Validitas Keterampilan Berwirausaha

\begin{tabular}{|c|c|c|c|}
\hline No & R hitung & R tabel $\boldsymbol{\alpha}=\mathbf{0 , 0 5} ; \mathbf{n}=\mathbf{3 3}$ & Keterangan \\
\hline 1 & 0,782 & $>0,44$ & Valid \\
\hline 2 & 0,758 & $>0,44$ & Valid \\
\hline 3 & 0,786 & $>0,44$ & Valid \\
\hline 4 & 0,690 & $>0,44$ & Valid \\
\hline 5 & 0,676 & $>0,44$ & Valid \\
\hline 6 & 0,505 & $>0,44$ & Valid \\
\hline 7 & 0,489 & $>0,44$ & Valid \\
\hline 8 & 0,598 & $>0,44$ & Valid \\
\hline 9 & 0,545 & $>0,44$ & Valid \\
\hline 10 & 0,706 & $>0,44$ & Valid \\
\hline 11 & 0,517 & $>0,44$ & Valid \\
\hline 12 & 0,507 & $>0,44$ & Valid \\
\hline 13 & 0,518 & $>0,44$ & Valid \\
\hline 14 & 0,571 & $>0,44$ & Valid \\
\hline 15 & 0,580 & $>0,44$ & Valid \\
\hline 16 & 0,735 & $>0,44$ & Valid \\
\hline 17 & 0,667 & $>0,44$ & Valid \\
\hline 18 & 0,504 & $>0,44$ & \\
\hline
\end{tabular}

\section{Uji Reliabilitas}

Reliabilitas untuk mengetahui sejauh mana hasil pengukuran tetap konsisten apabila dilakukan pengukuran dua kali atau lebih terhadap gejala yang sama dengan menggunakan alat pengukur yang sama pula. ${ }^{24}$ Pengujian reliabilitas pada penelitian ini dilakukan dengan cara mengkorelasikan skor item yang satu dengan yang lain dalam satu variabel. Suatu variabel dikatakan reliabel apabila memiliki Cronchbach Alpha $>0,60 .{ }^{25}$ Dalam penelitian ini, pengujian reliabilitas dilakukan dengan ketentuan jika nilai Cronchbach Alpha > 0,60, maka pernyataan pada variabel tersebut reliabel dan sebaliknya.

Tabel 1.5. Hasil Reliabilitas Keterampilan Berwirausaha

\begin{tabular}{|c|c|c|c|c|}
\hline No & Variabel & $\begin{array}{c}\text { Cronchbach } \\
\text { Alpha }\end{array}$ & $\begin{array}{c}\text { Cronchbach Alpha } \\
\text { yang Disyaratkan }\end{array}$ & Keterangan \\
\hline 1 & $\begin{array}{c}\text { Keterampilan } \\
\text { berwirausaha }\end{array}$ & 0,903 & 0,60 & Reliabel \\
\hline
\end{tabular}

Berdasarkan tabel di atas, dapat dijelaskan bahwa variabel keterampilan berwirausaha dengan nilai 0,903 termasuk reliabel, karena nilai Cronchbach Alpha >0,60, sehingga dapat digunakan dalam penelitian.

\footnotetext{
24 Ibid., 55

${ }^{25}$ Sofian Siregar, Metode Penelitian Kuantitatif, 57.
} 


\section{Uji Analisis Statistik Deskriptif}

Uji statistik deskriptif digunakan untuk mendeskripsikan data yang ada pada penelitian ini yang terdiri dari keterampilan berwirausaha $(\mathrm{X})$ dan profitabilitas usaha $(\mathrm{Y})$. Statistik deskriptif juga memberikan gambaran atau deskripsi suatu data yang dilihat dari nilai ratarata, standar deviasi, varian, maksimum, minimum, sum, range, kurtois (puncak distribusi), skewness (kemencengan distribusi). ${ }^{26}$

Tabel 1.6. Hasil Statistik Deskriptif Keterampilan Berwirausaha

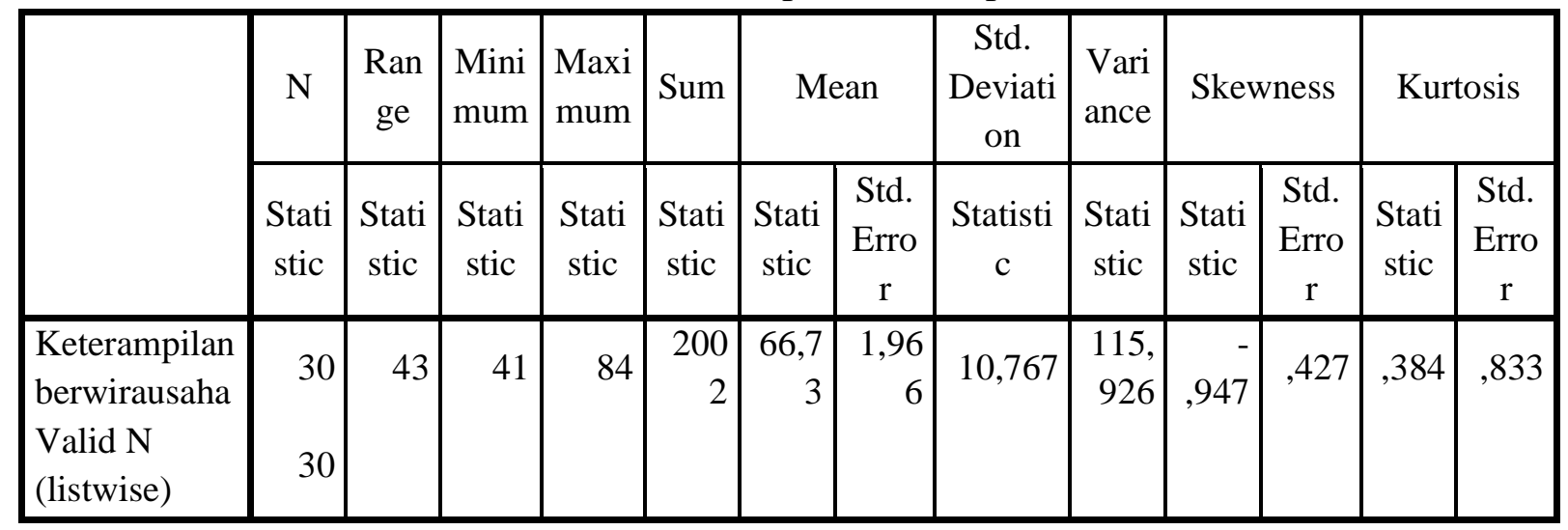

Dari tampilan tabel di atas, diketahui jumlah responden $(\mathrm{N})$ sebanyak 30 pedagang muslim. Dari 30 responden ini diketahui nilai minimum sebesar 41 dan nilai maksimum sebesar 84. Untuk nilai rata-rata (mean) sebesar 66,73 dengan standar deviasi sebesar 1,966.

Skewness dan kurtosis merupakan ukuran untuk melihat data yang digunakan berdistribusi normal atau tidak. Skewness mengukur kemencengan dari data dan kurtosis mengukur puncak dari distribusi data. Data dikatakan normal apabila mendekati nol. Hasil tampilan tabel di atas menunjukkan nilai skewness sebesar -0,947 dan nilai kurtosis sebesar 0,384 . Sehingga dapat disimpulkan bahwa variabel keterampilan berwirausaha berdistribusi normal dengan nilai range yang didapat sebesar 43 dari hasil pengurangan nilai maksimum dan minimum. Nilai sum merupakan penjumlahan dari nilai total dari 30 responden sebesar 2002.

Tabel 1.7. Hasil Persentase Skor Keterampilan Berwirausaha

\begin{tabular}{|c|l|c|c|c|c|}
\hline No & \multicolumn{1}{|c|}{ Indikator } & Skor Ideal & S skor & $\%$ & Kriteria \\
\hline 1 & Technical Skill & 300 & 240 & $80 \%$ & Tinggi \\
\hline 2 & Management Skill & 1500 & 1065 & $71 \%$ & Tinggi \\
\hline 3 & $\begin{array}{l}\text { Entrepreneurship } \\
\text { Skill }\end{array}$ & 300 & 210 & $70 \%$ & Tinggi \\
\hline 4 & $\begin{array}{l}\text { Personal Maturity } \\
\text { Skill }\end{array}$ & 600 & 487 & $81,16 \%$ & Tinggi \\
\hline \multicolumn{2}{|l|}{ Jumlah Skor Variabel X } & 2700 & 2002 & $74,14 \%$ & Tinggi \\
\hline
\end{tabular}

\footnotetext{
${ }^{26}$ Sugiyono, Statistika untuk Penelitian (Bandung: Alfabeta, 2017), 93.
} 
Berdasarkan hasil perhitungan analisis deskriptif presentase diketahui bahwa dari jawaban yang diberikan kepada responden melalui kuisioner mengenai keterampilan berwirausaha yang diwakili technical skill, management skill dan entrepreneurship skill dan personal maturity skill menunjukkan skor sebanyak 2002 dengan skor ideal 2700 atau sebanyak $74,14 \%$ dan memperoleh kriteria tinggi. Presentase tertinggi adalah personal maturity skill dengan persentase $81,16 \%$ atau termasuk dalam kriteria tinggi, sedangkan persentase terendah adalah indikator entrepreneurship skill dengan persentase $70 \%$ dan termasuk pada kriteria tinggi. Berdasarkan tabel di atas dapat dijelaskan bahwa keterampilan berwirausaha yang dimiliki oleh pedagang muslim di Pasar Sumput Driyorejo tergolong tinggi.

Tabel 1.8. Hasil Statistik Deskriptif Profitabilitas Usaha

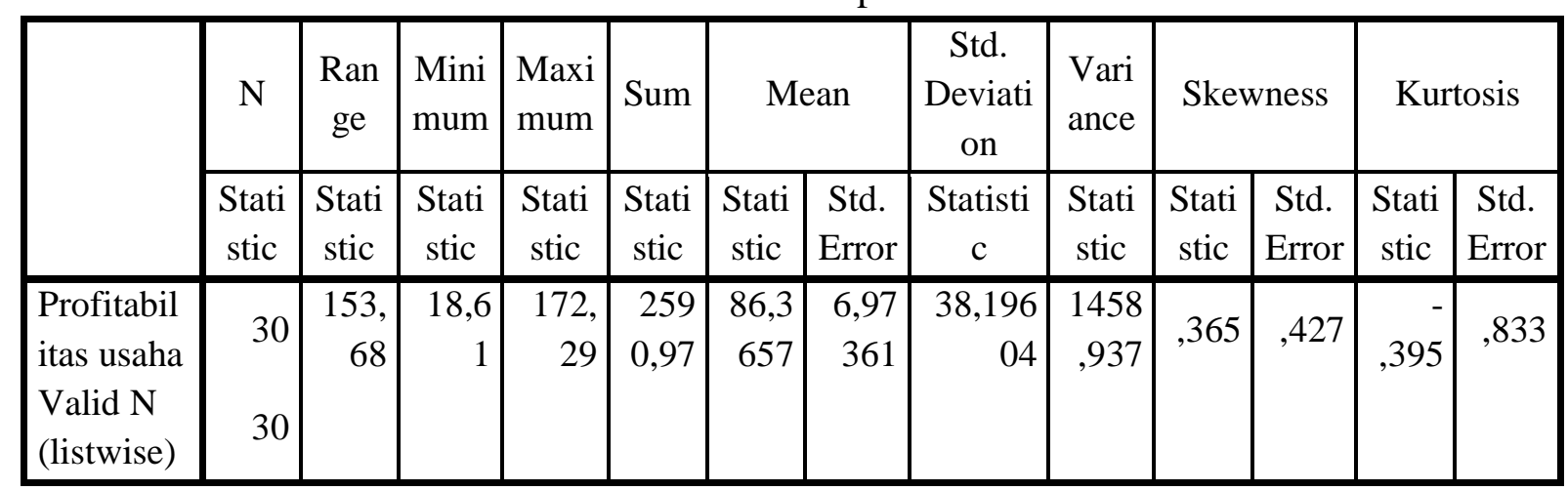

Dari tampilan tabel di atas, diketahui jumlah responden $(\mathrm{N})$ sebanyak 30 pedagang muslim. Dari 30 responden ini diketahui nilai minimum sebesar 18,41 dan nilai maksimum sebesar 172,29. Untuk nilai rata-rata (mean) sebesar 86,36 dengan standar deviasi sebesar 6,973 .

Skewness dan kurtosis merupakan ukuran untuk melihat data yang digunakan berdistribusi normal atau tidak. Skewness mengukur kemencengan dari data dan kurtosis mengukur puncak dari distribusi data. Data dikatakan normal apabila mendekati nol. Tabel di atas menunjukkan nilai skewness sebesar 0,365 dan nilai kurtosis sebesar -0,395. Sehingga dapat disimpulkan bahwa variabel profitabilitas usaha berdistribusi normal.

\section{Uji Regresi Linear Sederhana}

Analisis regresi linear sederhana digunakan untuk mengetahui seberapa besar pengaruh variabel independen terhadap variabel dependen. ${ }^{27}$ Analisis ini untuk mengetahui apakah masing-masing variabel independen berhubungan positif atau negatif. Hasil analisis regresi linear sederhana antara variabel independen, yaitu keterampialn berwirausaha serta variabel dependen, yaitu profitabilitas usaha diperoleh data berikut:

\footnotetext{
${ }^{27}$ Ibid., 284.
} 
Tabel 1.9. Coefficients Regresi Linear Sederhana

\begin{tabular}{|c|c|c|c|c|c|c|}
\hline \multirow{2}{*}{ Model } & & \multicolumn{2}{|c|}{$\begin{array}{l}\text { Unstandardized } \\
\text { Coefficients }\end{array}$} & \multirow{2}{*}{$\begin{array}{c}\begin{array}{c}\text { Standardized } \\
\text { Coefficients }\end{array} \\
\text { Beta }\end{array}$} & \multirow{2}{*}{$\mathrm{t}$} & \multirow{2}{*}{ Sig. } \\
\hline & & B & $\begin{array}{l}\text { Std. } \\
\text { Error }\end{array}$ & & & \\
\hline & (Constant) & $-19,776$ & 40,491 & &,- 488 & 629 \\
\hline 1 & $\begin{array}{l}\text { keterampilanb } \\
\text { erwirausaha }\end{array}$ & 1,591 & ,599 & ,448 & 2,654 & ,013 \\
\hline
\end{tabular}

Pada tabel coefficients di atas diketahui nilai konstanta $(\alpha)=-19,776$ dan variabel keterampilan berwirausaha (X) adalah 1,591. Angka konstan dari unstandardied coefficients dalam penelitian ini nilainya sebesar -19,776. Angka ini merupakan angka konstan yang mempunyai arti bahwa jika tidak ada keterampilan berwirausaha (X) maka nilai konsisten profitabilitas usaha (Y) sebesar -19,776. Sedangkan angka koefisien regresi nilainya sebesar 1,591. Angka ini mengandung arti bahwa setiap penambahan keterampilan berwirausaha (X), maka profitabilitas usaha (Y) akan meningkat sebesar 1,591 dengan anggapan nilai konstan sebesar $-19,776 .^{28}$

\section{Uji Parsial (Uji T)}

Uji ini dilakukan untuk mengetahui apakah variabel bebas, yaitu keterampilan berwirausaha (X) secara parsial signifikan terhadap variabel terikat, yaitu profitabilitas usaha $(\mathrm{Y})$. Ketentuan dalam uji $\mathrm{T}$ parsial yaitu dengan tingkat signifikan atau kepercayaan $(\alpha)$ sebesar $5 \%$ atau 0,05 . Kemudian ditentukan $t_{\text {tabel }}$ dengan rumus sebagai berikut:

$$
\mathrm{t}_{\text {tabel }}=\left(\frac{\alpha}{2}: \mathrm{n}-\mathrm{k}-1\right)
$$

Keterangan:

n: jumlah responden

$\mathrm{k}$ : jumlah variabel bebas

Sehingga, apabila dimasukkan nilainya pada rumus $t_{\text {tabel }}$ adalah sebagai berikut:

$$
\begin{aligned}
\mathrm{t}_{\text {tabel }} & =\left(\frac{\alpha}{2}: \mathrm{n}-\mathrm{k}-1\right) \\
& =\left(\frac{0,05}{2}: 30-1-1\right)=(0,025: 28)
\end{aligned}
$$

Maka, dengan pengujian dua sisi diperoleh angka (0,025:28) dapat dicari pada tabel distribusi $\mathrm{T}$ sehingga diperoleh nilai untuk $\mathrm{t}_{\text {tabel }}$ sebesar 2,048. Hipotesis (dugaan sementara) dalam uji T dapat ditentukan sebagai berikut. Pertama, tidak terdapat pengaruh keterampilan berwirausaha terhadap profitabilitas usaha pedagang muslim di Pasar Sumput Driyorejo $\left(\mathrm{H}_{\mathrm{o}}\right)$. Kedua, terdapat pengaruh keterampilan berwirausaha terhadap profitabilitas usaha pedagang muslim di pasar Sumput Driyorejo $\left(\mathrm{H}_{\mathrm{a}}\right)$.

\footnotetext{
${ }^{28}$ Ibid., 299.
} 
Tabel 1.10. Hasil Coefficients Uji T

\begin{tabular}{|c|r|r|r|r|r|}
\hline \multirow{2}{*}{ Model } & \multicolumn{2}{|c|}{$\begin{array}{c}\text { Unstandardized } \\
\text { Coefficients }\end{array}$} & $\begin{array}{c}\text { Standardiz } \\
\text { ed } \\
\text { Coefficient } \\
\mathrm{s}\end{array}$ & $\mathrm{t}$ & \multirow{2}{*}{ Sig. } \\
\cline { 2 - 6 } & \multicolumn{1}{|c|}{$\mathrm{B}$} & Std. Error & Beta & & \\
\hline \multirow{2}{*}{$1 \quad \begin{array}{l}\text { (Constant) } \\
\begin{array}{l}\text { Keterampilan } \\
\text { berwirausaha }\end{array}\end{array}$} & $-19,776$ & 40,491 & &,- 488 &, 629 \\
& 1,591 &, 599 &, 448 & 2,654 &, 013 \\
\hline
\end{tabular}

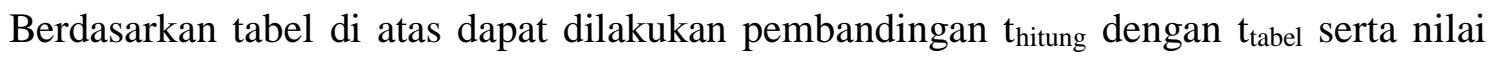
Sig. untuk mengetahui pengaruh masing-masing variabel bebas terhadap variabel terikat. Pada variabel keterampilan berwirausaha $(\mathrm{X})$ diperoleh nilai $t_{\text {hitung }}$ sebesar 2,654 dan nilai Sig. sebesar 0,013. Sehingga, karena nilai $t_{\text {hitung }}>t_{\text {tabel }}$ yaitu 2,654 > 2,048 dan nilai Sig. yaitu $0,013<0,05$ maka $\mathrm{H}_{\mathrm{o}}$ ditolak dan $\mathrm{H}_{\mathrm{a}}$ diterima, yang berarti bahwa terdapat pengaruh keterampilan berwirausaha $(\mathrm{X})$ terhadap profitabilitas usaha $(\mathrm{Y})$.

\section{Kesimpulan}

Berdasarkan hasil analisis statistik deskriptif di atas, keterampilan berwirausaha pedagang muslim di Pasar Sumput Driyorejo Gresik termasuk dalam kategori tinggi dengan nilai rata-rata presentase sebesar $74,14 \%$. Untuk hasil uji validitas dan reliabilitas data yang didapatkan juga bernilai valid dan reliabel dengan nilai validitas $>0,44$ dan nilai reliabilitas menggunakan Croncbach Alpha senilai 0,903. Sementara dari hasil analisis deskriptif, diketahui rata-rata RoA (return of assets) sebesar 86,36\%, yang artinya pengembalian aset yang diperoleh para pedagang berkisar pada rata-rata $86,36 \%$ dari modal yang dikeluarkan di awal usaha.

Dari hasil penelitian dari 30 pedagang muslim di Pasar Sumput Driyorejo melalui penyebaran kuesioner dan wawancara yang dilakukan, dihasilkan informasi bahwa terdapat pengaruh positif antara keterampilan berwirausaha terhadap profitabilitas usaha. Hal ini dibuktikan melalui analisis regresi sederhana. Dilihat dari persamaannya, koefisien bernilai positif. Artinya, terjadi pengaruh positif antara keterampilan berwirausaha terhadap profitabilitas usaha pedagang muslim di Pasar Sumput Driyorejo.

\section{Daftar Rujukan}

Alma, Buchari. Kewirausahaan untuk Mahasiswa dan Umum. Bandung: Alfabeta, 2016.

Hidayat, Anwar. "Penjelasan Tentang Uji Normalitas dan Metode Perhitungan" dalam http://www.statistikian.com/2013/uji-normalitas.html diakses pada 7 Desember 2018.

Pratama, Putri dan Jaharuddin. "Rekonstruksi Konsep Profitabilitas dalam Perspektif Islam", Ikraith-Humaniora, Volume 2, Nomor 1 (2018).

Raharjo, Sahid. "Cara Melakukan Uji Linearitas dengan Program SPSS" dalam https://www.spssindonesia.com/2014/02/uji-linearitas-dengan-program-spss.html? diakses pada 29 Desember 2018.

Rohim, Wawancara, Driyorejo, 27 September 2019. 
Setiawan dan Dwi Endah Kusrini. Ekonometrika. Yogyakarta: Andi Offset, 2010.

Setiorini, Ririn. "Analisis Pengaruh Modal Kerja Terhadap Profitabilitas Pada Perusahaan Manufaktur yang Terdapat di Bursa Efek Indonesia (BEI)”, Skripsi--UIN Syarif Hidayatullah Jakarta, 2009.

Siregar, Sofian. Metode Penelitian Kuantitatif: Dilengkapi dengan Perbandingan Perhitungan Manual dan SPSS. Jakarta: Kencana, 2017.

Sugiyono. Metode Penelitian Kuantitatif, Kualitatif, dan R\&D. Bandung: Alfabeta, 2012. . Statistika untuk Penelitian. Bandung: Alfabeta, 2017.

Suharso, Puguh. Metode Penelitian Kuantitatif untuk Bisnis: Pendekatan Filosofi dan Praktis. Jakarta: Indeks, 2009.

Sutik, Wawancara, Driyorejo, 16 Februari 2019.

Sutono, "Perilaku Konsumen Muslim dalam Mengkonsumsi Produk Halal Food Perspektif Maqāṣid al-shari’ah al-Shatibi (Studi Pada Pasar Sepanjang Taman Sidoarjo)" (Tesis-UIN Sunan Ampel Surabaya, 2018), 8.

Wibowo, Agus dan Sri Wartini. "Efisiensi Modal Kerja, Likuiditas dan Leverage Terhadap Profitabilitas Pada Perusahaan Manufaktur di BEI", Jurnal Dinamika Manajemen, Volume 3, Nomor 1 (Maret 2012).

https://Corporatefinanceinstitute.Com/Resources/Careers/Soft-Skills/Management-Skills/ diakses pada 2 September 2019.

https://skillspanorama.cedefop.europa.eu/sites/default/files/EUSP_AH_Entrepreneurial_0.pdf diakses pada 2 Agustus 2019.

http://repository.usu.ac.id/bitstream/123456789/42871/4/Chapter\%20II.pdf diakses pada 22 Februari 2019.

http://eprints.stainkudus.ac.id diakses pada 22 Februari 2019.

https://www.spssindonesia.com/2017/03/uji-analisis-regresi-linear-sederhana.html?m=1 diakses pada 9 Desember 2018. 